\section{Hydrobiologia}

Volume 588, Number 1 / septembre 2007: 109-124

http://dx.doi.org/10.1007/s10750-007-0656-z

(C) 2007 Springer

The original publication is available at http://www.springerlink.com
Archimer, archive institutionnelle de l'Ifremer http://www.ifremer.fr/docelec/

\title{
Modelling $\mathrm{Pb}$ and $\mathrm{Cd}$ dynamics in the Seine estuary
}

\author{
B. Thouvenin ${ }^{1, *}$, J. L. Gonzalez ${ }^{1}$, J. F. Chiffoleau ${ }^{2}$, B. Boutier ${ }^{2}$ and P. Le Hir ${ }^{3}$
}

(1) IFREMER BE/CM Centre de Toulon, Zone Portuaire de Brégaillon, BP 330, 83507 La Seyne-sur-Mer Cedex, France

(2) IFREMER BE/CM Centre de Nantes, Nantes Cedex, France

(3) IFREMER DYNECO/PHYSED Centre de Brest, Plouzane, France

*: Corresponding author : benedicte.thouvenin@ifremer.fr

\begin{abstract}
:
The Seine estuary (France) is currently one of the world's most contaminated estuaries, due in particular to its high cadmium and lead content. Proper understanding of contaminant transfer, transformation and retention mechanisms throughout the estuary and up to the adjacent marine zone require a range of studies involving data collections, experiments, and modeling tool. A multivariable transport model (SiAM-3D) was used to simulate dissolved and particulate transport and it is applied to several calculation grids; a speciation model (MOCO) was used to select key species and obtain a schematic system representation. The coupled model for $\mathrm{Cd}$ and $\mathrm{Pb}$ was compared with field measurements. The complementary character of various tools (model applied to annual time scale, in situ measurements and experiments) allowed to explore and quantify various hypotheses on the high dissolved cadmium concentrations observed during low river flow. The target is to achieve a compromise between acceptable computing times and adequate result accuracy. Although particle and contaminant behaviour is globally well-reproduced by the coarse grid, calculation errors relating to bayward fluxes and stocks deposited inside the estuary were highlighted after comparison with the fine grid.
\end{abstract}

Keywords : Seine estuary - Cd \& Pb trace metals - 3D-modeling 


\section{Introduction}

In the framework of the European Water Framework Directive, which aims to achieve "good water chemical status" by 2015, European states are now obliged to draw up environmental contamination assessments. Research must be conducted to identify the links between pollutant inputs and contamination levels in order to evaluate the future response of these environments to planning initiatives. This implies a good knowledge of contamination sources along with their transport modes in the various environmental compartments, which can be acquired using tools such as field measurements, laboratory experiments and mathematical modeling.

The Seine estuary is an interesting example of a highly-contaminated macrotidal system (Chiffoleau et al., 2001a). Due to the presence of strong physicochemical gradients and a well-characterized turbidity maximum, it constitutes a major zone for the accumulation and "recycling" of contaminants associated with particulate matter. Sediment transport representation is hence crucial to trace contaminant modeling, and is recognized as a major obstacle to the efficient simulation of chemical contaminants (Uncles, 2003), especially those which are strongly associated with particles.

Trace metals undergo various processes during fresh and salt water mixing; the evaluation of exchanges between dissolved and particulate phases is thus a key criteria for the determination of seaward fluxes and is a function of contaminant properties (hydrophobicity, affinity with dissolved ligands and/or the particulate phase (Comber et al., 1995, 1996; Standring et al., 2002, Ciffroy et al., 2003), particle properties (organic matter, oxide content etc. (Garnier et al., 1996; Turner et al., 2004, Ciffroy et al., 2003)) and physicochemical conditions occurring in the environment (salinity, suspended matter, $\mathrm{pH}$, etc.).

In terms of research, the complexity of these various processes necessitates multiplying model calculation points, coupled processes and variables describing the environment. However, this approach implies excessively long computing times and excludes routine use. It is also incompatible with demands for fast and easy-to-use tools expressed by environmental managers.

In response to these sometimes contradictory requirements and constraints, the majority of current modeling efforts therefore tackle just parts of the system or simplified systems (James, 2002): models are either one or two-dimensional, or dissolved/particulate exchange processes are simplified and represented using a $K_{D}$ partition coefficient which is constant or specific to the site (Wood et al .1995, Shrestha \& Orlob1996, Ng et al., 1996, Tappin et al., 1997, Mwanuzi et al., 1999, Uncles 2003, Gleizon et al., 2003, Wu et al, 2005). Numeric techniques and simplified approaches are also being developed (Atkinson et al., 1998, Uncles 2003, Perianez and Elliott 2002, Harris et al., 2003).

The purpose of this paper is to present the development and the validation of a coupled model which simulates the distributions and fluxes of cadmium and lead in the Seine estuary (France). The Cadmium's reactivity in the estuarine environment requires a fairly fine evaluation of heterogeneous processes, while lead necessitates an efficient simulation of particle transport.

\section{Study area: the Seine estuary}

The study site has been largely described in previous articles (Avoine et al, 1981, Lesourd et al., 2001, Le Hir et al., 2001a). The Seine estuary is $160 \mathrm{~km}$ long and limited upstream by a weir at Poses (Fig. 1). Mean river discharge is $410 \mathrm{~m}^{3} . \mathrm{s}^{-1}$, with highest flow rates exceeding $2,200 \mathrm{~m}^{3} . \mathrm{s}^{-1}$ and minimum rates equal to $40 \mathrm{~m}^{3} . \mathrm{s}^{-1}$ (Guezennec et al., 1999). The navigation channel has been regularized and deepened. The Seine estuary is open to the English Channel (Fig.1) and macrotidal, with a maximum tidal amplitude of $7 \mathrm{~m}$ in the vicinity of Le Havre and a salt intrusion limit between Tancarville and Caudebec.

The high turbidity maximum (TM) located between Tancarville and Honfleur is likely to get out of the estuary during high river runoff, then decrease in mass or settle on the lateral intertidal flats extending along the northern side of the mouth. Mean annual particulate discharge has been evaluated at around 650,000 tons (Guezennec et al., 1999). Waves generated by westerly winds in the Baie de Seine can induce resuspension and strongly contribute to the morphological evolution of the estuary mouth. 


\section{Methods}

\subsection{SiAM-3D, a dissolved/particulate transport model}

The model used here is the three-dimensional version of the SiAM Model ("Simulation d'Advection Multivariable") (Le Hir et al., 2001a, Cugier \& Le Hir 2002). This hydrodynamic model calculates currents and tidal excursion, taking into account actual winds. The transport equation is solved for all dissolved or particulate components. For the latter, flocculation processes are roughly accounted for by relating settling velocity Ws to total suspended matter concentrations, resulting in a second order polynomial relationship when concentrations are below $10 \mathrm{~g}^{-1}{ }^{-1}$, and a classical hindered settling formulation beyond (Le Hir et al., 2001b). Two particle classes are considered: so-called "heavy" particles with fast settling velocities $\left(W_{\min }=0.6 \mathrm{~mm} \mathrm{~s}^{-1}\right.$ and $\left.W_{\max }=1.5 \mathrm{~mm} \mathrm{~s}^{-1}\right)$, and "light" particles $\left(W_{\min }=0.1 \mathrm{~mm} \mathrm{~s}^{-1}\right.$ and $\left.W_{\max }=1 \mathrm{~mm} \mathrm{~s}^{-1}\right)$. The formulations used to reproduce erosion and deposition processes are clarified by Brenon \& Le Hir (1999) and Le Hir et al.(2001a). The management of sediment and settling processes is also taken into account. Wave contribution to bottom shear stress is computed using parameterizations recommended by Soulsby et al (1993).

The model is applied to the whole estuary, from the upstream dynamic tidal excursion limit at Poses weir to the Baie de Seine up to latitude $50^{\circ} 10 \mathrm{~N}$ (Fig. 1a).

Hydrodynamics are forced by the real tide which is introduced as an harmonic composition along the sea boundary, resulting from the tidal model developed by Simon \& Pineau (1999).

The computation grid is cartesian irregular. The grid is finer in the estuary zone, in particular around the northern mudflat and in the channel located between the dikes.

\subsection{Coupling SIAMBD with contaminants: development of several grids}

Describing sediment transport requires accurate field discretization in order to reproduce complex bathymetric variations and their effects on tidal current gradients: sediment trapping, erosion/deposition cycles, river flow and waves must hence be simulated. Widespread sensitivity testing is vital to the proper understanding of chemical contamination, and simulated time scales must be long (annual scale), meaning computing times must be reasonable. In order to combine these two approaches and respective constraints, the model is applied to several grids and results are subsequently compared to improve assessment of coarse grid computing limits. A fine grid (G1) is used as reference for sediment dynamics, with smallest discretization $500 \mathrm{~m} \times 120 \mathrm{~m}$ at the dikes (Fig. 2a). A coarse grid (G0) is used to test coupled hydrosedimentary / biogeochemical cycle models, with smallest discretization $2 \mathrm{~km} \times 1 \mathrm{~km}$ within the estuary (Fig. $2 \mathrm{~b}$ ). These two calculation grids are applied to the same zone, and boundary condition processing is identical.

\subsection{MOCO: an adsorption/desorption model}

Trace metal speciation is simulated using the MOCO surface complexation model, which treats adsorption on particles as a formation of complexes with functional surface groups (hydroxyls). Dissolved species are computed by solving the equilibria describing the metal's complexation with various dissolved ligands. This approach was detailed by Stumm et al. (1980), Bourg (1982), Westall (1987), Davis \& Kent (1990), Dzomback \& Morel (1990), Thouvenin et al. (1997) and Gonzalez et al. (2001a, 2001b). Although MOCO is capable of taking into account the various natural particle components (metal oxyhydroxides, organic matter) as individual adsorbent phases, it was used to process natural particles globally for the purposes of our study (use of mean sorption properties measured on particles from the Seine : Table 1). MOCO only deals with the exchangeable fraction adsorbed to the surface of particles, and assumes that cadmium adsorption/desorption systematically takes place at equilibrium. Experimental adsorption/desorption studies carried out on cadmium using particles from a variety of French estuaries (Gironde, Loire, Seine), have shown these reactions to be fast (equilibrium reached in just a few hours) (Dange, 2002; Gonzalez et al., 2001a, 2001b). Contaminant fractions incorporated in the crystalline mass or coprecipitated with various mineral or organic phases which only become soluble in specific environmental conditions (particular redox conditions or degradation of particulate organic matter, etc.) are generally considered as "nonexchangeable". Some studies on $\mathrm{Cd}$ biogeochemistry in the estuarine environment show that $\mathrm{Cd}$ behavior can be explained largely by its stability in chlorocomplex form and its rapid desorption during 
estuarine transit (Comans \& Van Dijk 1988; Boutier et al., 1993; Chiffoleau et al., 1994, Kraepiel et al., 1997). In addition, previous measurements (Chiffoleau et al., 2001a) and laboratory experiments (Gonzalez et al., 2001b) have revealed negligible $\mathrm{Cd}$ (and $\mathrm{Pb}$ ) associated with the colloidal fraction in the Seine estuary. Lastly, due to a lack of accurate knowledge on "complexating" organic ligand concentrations, acido-basic properties and complexation constants with regards to $\mathrm{Cd}$ and $\mathrm{Pb}$, this process has been unaccounted for so far. Previous validations of MOCO in the Seine, Gironde and Loire estuaries (Gonzalez et al, 2001a, 2001b) indicate that organic complexes only represent a small fraction of total dissolved $\mathrm{Cd}$.

\subsection{Coupling MOCO with the sediment model: processing simplification}

Coupling the MOCO model with dissolved/particulate transport models requires the quasi-systematic resolution of equilibrium equations at all times and at all points on the grid, due to the fact that the metal present in the water column continually redistributes itself between dissolved and particulate phases according to environmental conditions. The concentrations of each dissolved ligand must be known. We hence tested also a specific form of coupling, using MOCO as a preprocessing tool in order to simplify the problem and reduce computing times. The MOCO model is applied for a given contaminant on a broad spectrum of environmental conditions corresponding to the studied estuary. Partition coefficient variations were examined and laws were extracted to express dissolved/sorbed distribution as a function of key parameters.

The major dissolved ligands of cadmium, for example, are $[\mathrm{Cl}]$ derived from salinity, $\left[\mathrm{OH}^{-}\right]$computed from $\mathrm{pH}$ and $\left[\mathrm{SO}_{4}{ }^{2}\right]$. Stability constants for each dissolved complex is derived from Comans and Van Dijk (1988). Values at $25^{\circ} \mathrm{C}$ are used and the activity coefficients of the various species are calculated using the Davies equation. The average surface properties of Seine particles measured by Dange (2002) (Table 1) were used, along with testing of the two extreme value sets (minimum and maximum value measured for each parameter). The sensitivity study revealed the major role of chlorides in the dissolved/particulate partition of cadmium, plus the negligible influence of sulfate and $\mathrm{pH}$ variations (the latter may be more significant in fresh water). Conversely, results were sensitive to the parameter set selected to characterize particles. In the case of cadmium in the Seine estuary, a law expressing the partition coefficient log as a function of salinity alone was extrapolated from these results for an average parameter set characterizing particles (Fig 3). A similar function can also be used to express concentration ratios $[\mathrm{Cd} 2+] /[$ Total dissolved $\mathrm{Cd}]$ according to salinity.

\subsection{Field measurements}

The study of trace metal dynamics is based on a series of measurements:

$>$ field measurements used to assess actual concentrations, study and put forward hypotheses as to contaminant behavior, and validate models applied to the estuary: dissolved and particulate chemical contaminant measurements were collected during the "MARINA" cruises ("Seine-Aval" program) by Chiffoleau et al. (1994, 1999, 2001a, 2001b). Table 2 shows the main characteristics of these cruises, which cover a broad range of flow situations and explore the entire estuary zone.

$>$ Lateral input measurements are performed to evaluate fluxes entering the estuary via the river or intra-estuarine inputs. The SNS measurements (1988-2001) conducted at Poses weir every 10-15 days for many years offer useful data on the variability of these inputs and have led to a better evaluation of the relationships between metal and suspended matter concentrations (see example of lead, Fig. 4a). Far less data is available on intra-estuarine inputs from factories and urban discharges: actual flux evaluations are vague.

$>$ Measurements and laboratory experiments are used to estimate parameters and data which cannot be measured directly: The "mobilizable" fraction of metal contaminants during estuarine transit is estimated on the basis of contaminant desorption experiments on particles taken at Poses (estuary entrance) and immersed in filtered sea water for 35 days (Thouvenin et al., 2003). As oxygenation conditions were not maintained and controlled, this "mobilizable" fraction incorporates the exchangeable fraction and a more-or-less large portion of fractions which dissolve during organic matter degradation, or in suboxic or anoxic conditions. Cadmium exchangeable fraction evaluations are based on the comparison of natural $\mathrm{Cd}$ distribution coefficients measured during various in situ cruises with the distribution coefficients of ${ }^{109} \mathrm{Cd}$ defined during adsorption experiments. (Gonzalez et al., 2001a, 2001b)

$>$ The major role of intertidal and subtidal mudflats as potential sources (by erosion and/or diffusion) of metal contaminants was explored by measuring metal concentrations in particles and pore 
waters of sediment arising from the northern mudflat (intertidal zone) and Banc du Ratelet (subtidal zone) (Fig. 1) (Thouvenin et al., 2003).

\section{Results}

The results presented here are mainly those obtained with the coupled model, fed by or confronted with the above-mentioned measurements.

\subsection{Coupled model validation.}

The hydrodynamic model, dissolved/particulate transport model and chemical model have been individually examined and validated (Le Hir et al., 2001a, Cugier \& Le Hir 2002, Gonzalez et al., $2001 \mathrm{a}, 2001 \mathrm{~b})$. The coupled model simulates variations in contaminant concentrations in the estuary and Baie de Seine, starting out with a period of high river flow in order to minimize the impact of initial values. This initial state is the result of a simulation of hydrodynamic, salinity and SM concentrations over several months. The model is applied over a one-year period. The results obtained for typical high and low river flows are subsequently compared with cruise measurements at high and low river flows. Various hypotheses are then tested, e.g. introduction of additional processes (solubilization by degradation of particulate organic matter), homogeneous or heterogeneous adsorption to light and heavy particles, use of MOCO equations or MOCO KD laws. Data uncertainties are also introduced (exchangeable fraction, inputs, complexation constant, upstream partition coefficient, etc.). The results of some of these tests are presented on figures 5 and 6 ; a degree of fluctuation is allocated to model results, represented by mean values and variation intervals.

\subsection{Cadmium distribution:}

According to various evaluations (Gonzalez et al., 2001a, 2001b), the exchangeable particulate fraction of $\mathrm{Cd}$ corresponds to around $10 \%$ of bulk particulate $\mathrm{Cd}$. Total particulate cadmium concentrations computed by the model are similar to measurements, with values ranging from 3 to 4 $\mathrm{mg} \mathrm{kg}^{-1}$ in the upstream estuary, then decreasing to under $1 \mathrm{mg} \mathrm{kg}^{-1}$ in the turbidity maximum (TM) zone (Fig. 5a). Dissolved cadmium concentrations differ to varying degrees according to cruises. The selection of model results shown on Figure $5 \mathrm{~b}$ clearly highlights weak upstream concentrations (10 to $40 \mathrm{ng} \mathrm{I}^{-1}$ ) and an increase in estuarine concentrations when salinity increases and particles are desorbed from their exchangeable fraction. Discrepancies may be due to atypical $\mathrm{Cd}$ distribution, as was the case in June 1996 (Marina 6; Fig. 5b), or to a shift in the TM computed by the model. Dissolved cadmium concentrations computed during low river flow are underestimated in comparison to most cruises, i.e. TM particle desorption does not systematically explain the high concentrations observed.

\subsection{Lead distribution:}

Particulate lead concentrations vary widely in the upstream estuary (around 50 to $200 \mathrm{mg} \mathrm{kg}^{-1}$ ) (figure $6 a)$; the model also shows strong variations incurred by input uncertainties, variations in the partition coefficients of particles arriving from the river, and lead's particular affinity with light or heavy particles. The stablest TM concentration (around $100 \mathrm{mg} \mathrm{kg}^{-1}$ when salinity ranged from 0 to around 25) is reproduced by the model. Constant particulate $\mathrm{Pb}$ (and $\mathrm{Cd}$ - figure $5 \mathrm{a}$ ) concentrations for salinities greater than 25 were measured during the Marina 5 cruise. These measurements were poorly reproduced by MOCO during the simulation period: the model does not reproduce the increased downstream dispersion of the Seine particle plume observed during this major spate of February 1995. Dissolved lead concentrations also vary widely in the upstream estuary (around 200 to $600 \mathrm{ng} \mathrm{I}^{-1}$ figure $6 \mathrm{~b}$ ); they dilute in sea water and drop to low concentrations of around $20 \mathrm{ng} \mathrm{l}^{-1}$. Measured concentrations plotted as a function of salinity (figure $6 \mathrm{~b}$ ) showed a quasi-conservative behavior when salinity increased. In view of the results of our desorption experiments, whereby particulate concentrations remained constant throughout a 35-day immersion, the exchangeable fraction was presumed to be negligible for this contaminant, and a partition coefficient was applied to total lead introduced into the estuary $\left(K_{D}=300-700 \mathrm{l} / \mathrm{g}-\mathrm{Fig} 4 \mathrm{~b}\right)$. 


\subsection{Calculation of contaminant fluxes crossing the estuary:}

Contaminant transfer from river to sea can be studied by computing fluxes crossing various estuary sections. These fluxes vary widely in the middle estuary between Le Havre and Tancarville due to intense and alternating circulation caused by tides. Residual fluxes are therefore estimated by computing cumulated fluxes of contaminant crossing the estuary section over time. An example of variations in cumulated particulate lead fluxes (Fig. 7) at Poses, Caudebec (upstream estuary), Honfleur (salinity front), La Hève (open mouth) and Ouistreham/Antifer (eastern bay) illustrates the dynamics of this component during a flood lasting approximately 50 days, followed by a 150-day low river flow cycle. Upstream flux arriving at Poses is particularly high during floods (around 45 tons in one month), but remains low during low river flow (around 10 tons in 3.5 months). Flux evolution at Caudebec is similar although a less significant increase is observed during floods, due to the fact that part of contaminated particles are deposited in the upstream estuary (in the mudflats and especially in Rouen port). Further downstream at Honfleur and La Hève, particulate lead fluxes oscillate (up to 5 tons during a tidal cycle at Honfleur) during spring tides, and residual flux also increases with river flow. A slight reduction is observed during the post-flood period, when the TM shifts upstream. Input from the flood takes over a month to arrive at Ouistreham/Antifer in the bay (26 km to the West and 30 $\mathrm{km}$ to the North of Cap de la Hève).

On an annual scale, net fluxes to the Baie de Seine obviously depend on river inputs during the year, but also on inputs during previous days and months. They are also the result of sediment dynamics and the more-or-less large particle stocks deposited in the estuary mouth, which may be re-suspended according to winds and lunar tidal cycles.

The comparison of particle fluxes computed by the model using the two grids shows significant intraestuarine differences, e.g. at Honfleur and even at the mouth of the navigation channel. Figure 8 compares the evolution of upstream and net particle fluxes computed using the fine grid G1 and the coarse grid G0 at three different periods (1997, 2002 and 2003), with same initial condition. In comparison to G1, G0 global calculation errors on net fluxes leaving the estuary can currently exceed $30 \%$ of upstream gross flux at certain periods. The sudden matter flush corresponds to a conjunction of strong gales and spring tide, which resuspend and export particles northwards (Le Hir et al., 2001a); this effect is more significant on the coarse grid.

\section{Discussion}

\subsection{Uncertainties in terms of processes}

A number of estuary experiments and studies demonstrate lead's affinity with particles (Shukin \& Bogdanova, 1998, 2003, Westerlund et al, 1986) and its low reactivity during fresh and marine water mixing (Window et al, 1985, Kraepiel et al, 1997). The dissolved lead maxima observed by Boutier (1993) in the Loire estuary were assigned to industrial waste inputs in the zone. During their Mersey estuary cruise, Martino et al (2002) also observed dissolved lead maxima in lower salinity waters, leading them to suggest the key source of dissolved metal was desorption from fine resuspendable bed particles, possibly supplemented by the degradation of metal-bearing sediment organic matter. Robert et al (2004) measured the discontinuity of dissolved $\mathrm{Pb}$ concentrations on the sediment surface in the Gironde estuary; their experiments showed intensive metal mobilization in the soft mud layer due to redox-induced dissolution. No dissolved lead concentration maxima were observed in the Seine estuary water column (Chiffoleau et al, 1994, 1999 - figure 6). Some adsorption/desorption processes occur in the estuary (especially in fresh water), but these are masked by the natural variability of inputs and their characteristics (partition coefficient and lead concentration). Primarily particulate character of lead induces complex behavior when associated with particle dynamics. Particles do not constitute an easy-to-identify, homogeneous unit; their heterogeneity is represented in a simplified manner in the model by two classes of particles only differentiated by settling velocity. But the affinity of lead with one class or the other is not known. Measurements have shown that the partition coefficient relating to particle properties (Turner \& Millward 1994, Garnier et al., 1996, Santschi et al, 1997, Ciffroy et al., 2003 ) is highly variable in the upstream river ( $K_{D}$ varies by several log, fig $4 b$, SNS, 1998 to 2001). Applying the model on the basis of differing affinity with the two particles fractions ( $\mathrm{K}_{\mathrm{D}} /$ light particles $\neq$ $\mathrm{K}_{\mathrm{D}} /$ heavy particles) results in longitudinal variations in total particulate lead concentrations like those observed in situ. These uncertainties are coupled with doubts on input quantification. Differences in computed versus measured concentrations of dissolved lead could be explained by higher and more 
variable real inputs during certain cruises (Marina 3 in November 1992 and Marina 4 in September 1994).

Regarding cadmium, the majority of macrotidal estuaries show an increase followed by a drop in dissolved Cd concentrations according to salinity (Elbaz-Poulichet et al., 1987; Boutier et al., 1993; Chiffoleau et al., 1994, Turner, 1996 ). The majority of field studies assign this characteristic evolution to the desorption of cadmium from particles entering the estuary.

Model application during high river flow confirms that dissolved cadmium concentrations in the salty estuary depend primarily on exchangeable particulate cadmium fluxes arriving upstream and desorbed while crossing estuary (Gonzalez et al., 2001b). During low river flow, however, upstream cadmium flux is very weak and TM particles only possess a very small fraction of metal available for desorption. Thanks to long-term simulations capable of reproducing seasonal continuity, the model highlights the fact that the desorption process is not solely responsible for the observed increase; a dissolved cadmium source of around 1 to $3 \mathrm{~kg} \mathrm{~d}^{-1}$ remains unaccounted for. This source may be of several origins:

- Lack of information on inputs, in particular during the first cruises $(1994,1996)$. Major cadmium discharges by phosphogypsum factories around Le Havre were eliminated in 1992, but could have caused residual input for the following two years due to desorption from particles which were not evacuated towards the bay or buried in sediments. A dissolved cadmium intra-estuarine input was detected during the June 1996 cruise and estimated at less than $1 \mathrm{~kg} \mathrm{~d}^{-1}$ (Chiffoleau et al., 2001a); this input came from rainwater percolation of contaminated industrial wastes and stopped in late 1996.

- The degradation of organic matter contained in Seine particles (POC $=10 \%$ of the particles upstream and 3\% in the TM) can also account for a dissolved cadmium input of around $1 \mathrm{~kg} \mathrm{~d}^{-1}$ (estimate based on evaluations of degraded organic matter in the estuary Even et al.,2004; J. Garnier, pers. comm.).

- The mudflats located in the upstream estuary wax during high river flow and tend to wane gradually during low flow (Guezennec et al., 1999). This additional contribution of particles rich in desorbable fractions can be estimated at approximately $0.5 \mathrm{~kg} \mathrm{~d}^{-1}$.

- In the Northern intertidal mudflats, dissolved cadmium concentrations in pore waters are significant (100 to $200 \mathrm{ng} \mathrm{I}^{-1}$, reaching nearly 1,000 $\mathrm{ng} \mathrm{I}^{-1}$ at some isolated points (Thouvenin et al., 2003)). A rough estimate of fluxes originating from sediments (by diffusion and erosion) based on measurements in pore waters gives very low values (a few kilos per year) (Thouvenin et al, 2004).

- Lastly, experiments conducted by Standring et al. (2002), Ciffroy et al. (2003) and Millward \& Liu (2003) showed cadmium could also undergo slow adsorption/desorption reactions. Concentrations measured in TM particles are generally higher than residual values measured during desorption experiments $\left(0.3 \pm 0.07 \mathrm{mg} \cdot \mathrm{kg}^{-1}\right)$. Particles remain in the estuary for several months; they undergo erosion/deposit cycles, including probable deposit phases in anoxic conditions (Ouddane et al., 2001, Thouvenin et al, 2004), influenced by complex organic matter transformation processes which tend to modify particle surface sites. The deficit may be partially explained by the fact that these slow kinetic processes, along with variations in particle surface properties, are not taken into account.

These estimates - based on measurements and evaluations - must be fine-tuned. They do, however, appear to demonstrate that although none of these processes alone accounts for the missing $\mathrm{Cd}$, each has its own importance: dissolved cadmium fluxes exported baywards are underestimated by the model if these inputs and processes are not taken into account. Regarding concentrations, error could reach up to $50 \%$ during low river flow (versus certain cruises).

\subsection{Uncertainties due to calculation grids}

Users are unwilling to accept more than a few hours computing time to obtain 12-monthly projections on a given element. Grid G0 is therefore used to provide a preliminary analysis of contaminant dynamics (computing time 2-3 hours). The fine grid (G1) is mainly used as reference for sediment transport (57h CPU at $1 \mathrm{GHz}$ needed for a 12-month salinity and SPM projection), but it can be also 
be used for contaminant simulation as required. It is obvious that even the so-called fine grid has application limits. A number of uncertainties were highlighted, in particular due to the simplification of flocculation processes, settling, wave propagation, non-evolutionary particle representation and the fact that dredging and sand/mud mixing are not taken into account. These uncertainties are increased with coarse grids, which do not reproduce circulation in uneven zones, tend to smooth gradients (Fig. 10) and offer poorer deposit zone identification (Fig. 11), hence resulting in amended assessments. Results can be improved and loopholes identified (e.g. deposits on North intertidal mudflat underestimated and seaward outflux overestimated by about $30 \%$ ) by comparing the grids and modifying certain parameters or correcting certain depths interpolated in highly disturbed areas.

Crossing flux calculations highlighted the importance of the choice of initial conditions; particulate fluxes are a function of slow processes and environmental conditions dating back several months. This confirms the need for long simulations, despite the fact that the latter favor error accumulations due to model spatial discretization or to slow processes which are either unaccounted for, or simplified (slow desorption, solubilization in sediments, consolidation process, etc.). The model's limited ability to reproduce particle tendency to resuspend during major events such as spring tides or gales introduces uncertainties on calculated particle retention times. The coarse grid G0 does not perform well on this point.

\section{Conclusion}

Multivariable three-dimensional dissolved/particulate transport models, coupled with biogeochemical processes for the simulation of trace metal dynamics, constitute powerful analysis tools in coastal zones such as estuaries, where physicochemical gradients are strong and particle retention time is long. But the numerous uncertainties encountered in terms of both sedimentary and chemical processes, associated with a lack of data to feed the models are currently (and will certainly remain) a major hurdle.

Particulate contaminant dynamics can be reliably tackled thanks to fine model ability to simulate sediment transport, but fine processes are masked by natural variability and inaccurate data on inputs and particle properties. In view of lead's strong affinity with particles ( $94 \%$ of upstream input is particulate (Chiffoleau, 2001b)), and dissolved lead's quasi-conservative behavior in the saline estuary, we can, at least for the time being, adopt a theory of non-exchange between dissolved and particulate phases in the Seine estuary to obtain satisfactory concentration evaluations. Due to cadmium's high reactivity with chlorides and its affinity with organic matter, finer chemical processes must be taken into account to obtain acceptable long-term evaluations. In order to refine our results, we need to gain more data on both lead and cadmium inputs into the estuary (variability and properties), and conduct additional detailed laboratory experiments to achieve a better approach to exchange and speciation processes.

Global contaminant behavior and concentrations were well reproduced using the coarse grid, once the latter had been verified and improved by comparison with the fine grid. This result means long time scales can be simulated with acceptable computing times, but the errors and uncertainties inherent to overly-coarse grids must nevertheless be taken into account.

\section{Acknowledgements}

This work was partially carried out in the framework of the Seine Aval program, financed by the French Government, the Haute Normandie region, the other regions of the Paris Basin, the Seine Normandie Water Agency (AESN) and the industrial firms of Haute Normandie. The authors would like to thanks the captains and crews of N/O Thalia and Maïmiti, the Seine Navigation Service antipollution unit for supplying most of the samples used for the experiments and providing the estuary database, the Rouen Port Authority for providing hydrographic and bathymetric data and B. Simon (SHOM: Service hydrographique et océanographique de la Marine) for providing tidal harmonic components in the Baie de Seine. Thanks also to L. Valentine for translation and S. Even for her helpful comments.

\section{References}

Atkinson J.F., S.K. Gupta, J.V. DePinto \& R.R. Rumer, 1998. Linking hydrodynamic and water quality models with different scales. Journal of Environmental Engineering, May 1998: 399-408 
Avoine J; G.P. Allen, M. Nichols, J.C. Salomon \& C. Larsonneur, 1981. Suspended sediment transport in the Seine estuary, France: Effect of man-made modification on estuary-shelf sedimentology. Marine Geology 40: 119-137

Bourg A.M., 1982. ADSORP, a chemical equilibria computer program accounting for adsorption processes in aquatic systems. Environmental Technology Letters $3: 305-310$.

Boutier B., J.F. Chiffoleau, D. Auger \& I. Truquet, 1993. Influence of the Loire river on dissolved lead and cadmium concentrations in coastal waters of Brittany. Estuarine Coastal Shelf Science, 36: 133145.

Brenon I \& P. Le Hir, 1999. Modelling the turbidity maximum in the Seine estuary (France): Identification of formation processes. Estuarine, Coastal and Shelf Science 49: 525-544

Chiffoleau J.F., D. Cossa D., D. Auger \& I. Truquet I, 1994. Trace metal distribution, partition and fluxes in the Seine estuary (France) in low discharge regime. Marine Chemistry $47: 145-158$.

Chiffoleau J.F., D. Auger \& E. Chartier, 1999. Fluxes of selected trace metals from the Seine estuary to the eastern English Channel during the period august 1994 to july 1995. Continental Shelf Research 19: 2063-2082

Chiffoleau J.F., D. Auger, E. Chartier, P. Michel, I. Truquet, A. Ficht, J.L. Gonzalez \& L.A. Romana, 2001a. Spatiotemporal changes in cadmium contamination in the Seine Estuary (France). Estuaries. 24, 1029-1040.

Chiffoleau J.-F., D. Claisse, D. Cossa, A. Ficht, J.L. Gonzalez, T. Guyot, P. Michel, P. Miramand, C. Oger \& F. Petit, 2001b. La contamination métallique. Programme scientifique "Seine Aval». Fascicule $n^{\circ} 8$. IFREMER Editions. Plouzané (France), $39 \mathrm{p}$.

Ciffroy P., J.M. Garnier \& L. Benyahya, 2003. Kinetic partitioning of Co, Mn, Cs, Fe, Ag, Zn and Cd in fresh waters (Loire) mixed with brackish waters (Loire estuary): experimental and modelling approaches. Marine Pollution Bulletin 46 : 626-641

Comans R.N.J. \& C.P.J. Van Dijk, 1988. Role of complexation processes in cadmium mobilization during estuarine mixing. Nature, 336: 151-154.

Comber S.D.W., A.M. Gunn \& C. Whalley, 1995. Comparison of the partitioning of trace metals in the Humber and Mersey Estuaries. Marine Pollution Bulletin $30: 12: 851-860$

Comber S.D.W., M.J. Gardner, A.M. Gunn \& C. Whalley, 1996. Kinetics of trace metal sorption to estuarine suspended particulate matter. Chemosphere Vol 33: 1027-1040

Cugier P.\& P.Le Hir , 2002. Development of a 3D hydrodynamical model for coastal ecosystem modelling. Application to the plume of the Seine River. Estuar. Coast. Shelf. Sci., 55, 673-695.

Dange C.,2002. Etude du comportement des éléments traces en milieu estuarien: approche expérimentale et modélisation. Thèse Université de Reims Champagne-Ardennes. $467 \mathrm{p}$.

Davis J. A. \& D.B. Kent. 1990. Surface complexation modelling in aqueous geochemistry, p 177-260. In M. F. Hochella and A. F. White (eds.), Mineral-water interface geochemistry, Reviews in Mineralogy, vol 23.

Dzombak, D.A. \& F.M.M. Morel. 1990. Surface complexation modeling: Hydrous ferric oxide. John Wiley, New York.

Elbaz-Poulichet F., W.W. Huang, J.M. Martin \& J.X. Zhu, 1987. Dissolved cadmium behaviour in some selected French and Chinese estuaries. Consequences on cadmium supply to the ocean. Marine Chemistry, 22: 125-136.

Even S., A. Ficht, B. Thouvenin, J. Garnier, P. Servais \& P. Le Hir, 2006. Modelling the carbon cycle in the turbidity maximum of the Seine estuary. In SIL Proceedings : Verh. Internat. Verein. Limnol.,29(5),2263-2266.

Garnier J.M., J.M Martin, J.M. Mouchel \& K. Sioud, 1996. Partitioning of trace metals between the dissolved and particulate phases and particulate surface reactivity in the Lena River estuary and the Laptev Sea (Russia). Marine Chemistry 53: 269-283

Garnier J., P. Servais, G. Billen, M. Akopian \& N. Brion, 2001. Lower Seine River and Estuary (France) Carbon and Oxygen Budgets During Low Flow. Estuaries; Vol 24: pp 964-976

Gleizon P., A.G. Punt \& M.G. Lyons, 2003. Modelling hydrodynamics and sediment flux within a macrotidal estuary: problems and solutions. The Science of the Total Environment 314-316: 589-597

Gonzalez J.L., C. Dange \& B. Thouvenin (2001a) Spéciation des contaminants métalliques en milieu estuarien : Intérêt de la modélisation et application au cadmium. Hydroécologie Appliquée. 13 : 37-55 Gonzalez J.L. , Thouvenin B., Dange C., Fiandrino A., and J.F. Chiffoleau (2001b). Modeling of Cd speciation and dynamics in the Seine estuary (France). Estuaries, 24, 6B, 1041-1055.

Gonzalez-Davila M., 1995. The role of phytoplankton cells on the control of heavy metal concentration in seawater. Marine Chemistry 48: 215-236. 
Guezennec L., R. Lafite, J.P. Dupont, R. Meyer \& D. Boust, 1999. Hydrodynamics of suspended particulate matter in the tidal freshwater zone of a macrotidal estuary (The Seine estuary, France). Estuaries 22: 717-727

Harris J.R.W. \& R.N. Gorley, 2003. EcoS, a framework for modelling hierarchical spatial systems. The Science of the Total Environment 314-316: 625-635

James I.D., 2002. Modelling pollution dispersion, the ecosystem and water quality in coastal waters: a review. Environmental Modelling \& Software 17: 363-385

Kraepiel A.M., J.F. Chiffoleau., J.M. Martin \& F.M.M. Morel, 1997. Geochemistry of trace metals in the Gironde estuary. Geochimica Cosmochimica Acta. 61: 1421-1436

Le Goff F.,2002. Apports des contaminants chimiques en estuaire de Seine. Rapport de stage DESS «Evaluation des Risques Environnementaux ». Université du Havre. INERIS - IFREMER (Cellule ARC). $41 p+$ annexes + CD-ROM.

Le Hir P., A. Ficht, R. Silva Jacinto, P. Lesueur, J.P. Dupont, R. Lafite, I. Brenon, B. Thouvenin \& P. Cugier, 2001a. Fine sediment transport and accumulations at the mouth of the Seine estuary (France). Estuaries, Vol 24: 950-963

Le Hir P., P. Bassoullet and H. Jestin, 2001b. Application of the continuous modeling concept to simulate high-concentration suspended sediment in a macrotidal estuary. In Coastal and Estuarine Fine Sediment Processes (McAnally and Mehta Eds), Proceedings in Marine Science $\mathrm{N}^{\circ} 3$, Elsevier, pp.229-247

Lesourd S., P. Lesueur , J.C. Brun-Cottan, J.P. Auffret, N. Poupinet \& B. Laignel, 2001. Morphosedimentary evolution of the macrotidal Seine Estuary subjected to human impact. Estuaries, Vol 24: 940-949

Martino M., Turner A., Nimmo M., Millward G.E., 2002. Resuspension, reactivity and recycling of trace metals in the Mersey Estuary, UK. Marine Chemistry $77: 171-186$

Millward G.E. \& Y.P. Liu, 2003. Modelling metal desorption kinetics in estuaries. The Science of the Total Environment. 314-316: 613-623

Mwanuzi F.(ou Mwanzi ?) \& F. De Smedt, 1999. Heavy metal distribution model under estuarine mixing. Hydrological processes 13: 789-804

$\mathrm{Ng}$ B., A. Turner, A.O. Tyler, R.A. Falconer \& G.E. Millward, 1996. Modelling contaminant geochemistry in estuaries. Water Research Vol 30: 63-74

Ouddane B., D. Boust, E. Martin, J.C. Fischer \& M. Wartel, 2001. The Post-Depositional Reactivity of Iron and Manganese in the Sediments of a macrotidal Estuarine System. Estuaries, Vol 24: 1015-1028 Perianez R. \& A.J. Elliott, 2002. A particle-tracking method for simulating the dispersion of nonconservative radionuclides in coastal waters. Journal of Environmental radioactivity Vol 58, Issue 1: 13-33

Robert S., Blanc G., Schäfer J., Lavaux G., Abril G., 2004. Metal mobilization in the Gironde Estuary (France) : the role of the soft mud layer in the maximum turbidity zone. Marine Chemistry 87: 1-13

Santschi P.H.,Lenhart J.J., Honeyman B.D., 1997. Heterogeneous processes affecting trace contaminant distribution in estuaries: The role of natural organic matter. Marine chemistry $58: 99-125$ Shrestha P.L. \& G.T. Orlob, 1996. Multiphase distribution of cohesive sediments and heavy metals in estuarine systems. Journal of Environmental Engineering, Vol 122: 730-740

Simon B \& Pineau, 1999. Amélioration du modèle de prédiction de la marée en Manche. Rapport d'étude du SHOM 28/05/99 . N 282 EPSHOM/CH/GG/ET/NP

Shukin VM, Bogdanova NN, 1998. The influence of anthropogenic contamination on metals release from coastal sediment suspensions with aerated seawater. Chem. Ecol. 15, p 87-102;

Shukin VM, Bogdanova NN,2003. Mobilization of metals from riverine suspended matter in seawater. Marine Chemistry, 83, p 157-167.

SNS (Service de navigation de la Seine) Cellule antipollution, 1988 to 2001. Suivi de la qualité des eaux de la Seine à l'aval de Poses. Bilan de chaque année. Agence de l'eau Seine Normandie.

Soulsby R.L., L. Hamm, G. Klopman, D. Myrhaug, R.R. Simons, G.P. Thomas, 1993. Wave-current interaction within and outside the bottom boundary layer. Coastal Engineering, Vol 21:, 41-69

Standring W.J.F., D.H. Oughton \& B. Salbu, 2002. Remobilization of ${ }^{109} \mathrm{Cd}$, ${ }^{65} \mathrm{Zn}$ and ${ }^{54} \mathrm{Mn}$ from freshwater-labelled river sediments when mixed with seawater. Environment International 28: 185-195 Stumm W., R. Kummer \& L. Sigg, 1980. A ligand exchange model for the adsorption of inorganic and organic ligands at hydrous oxide interfaces. Croatica Chemica Acta 53: 291-312

Tappin A.D., J.D. Burton, G.E. Millward \& P.J. Statham, 1997. A numerical transport model for predicting the distributions of $\mathrm{Cd}, \mathrm{Cu}, \mathrm{Ni}, \mathrm{Pb}$ and $\mathrm{Zn}$ in the southern North Sea: the sensitivity of model results to the uncertainties in the magnitudes of metal inputs. Journal of Marine Systems 13: $173-204$ Thouvenin B., J.L. Gonzalez \& B. Boutier, 1997. Modelling of pollutant behaviour in estuaries. Marine Chemistry, 58, 147-161. 
Thouvenin B., B. Boutier, J.F. Chiffoleau, J.L. Gonzalez \& P. Michel, 2003. Contribution à l'étude de la dynamique et de la spéciation des contaminants. Rapport d'activité 2002. Projet Seine Aval 2 : Thème Analyses des risques chimiques et microbiologiques. $44 \mathrm{pp}$.

Thouvenin B., B. Boutier, J.F. Chiffoleau \& J.L. Gonzalez, 2004. Contribution à l'étude de la dynamique et de la spéciation des contaminants. Rapport d'activité 2003. Projet Seine Aval 2 : Thème Analyses des risques chimiques et microbiologiques. $98 \mathrm{pp}$.

Turner A. \& G.E. Millward, 1994. Partitioning of Trace Metals in a Macrotidal Estuary. Implications for contaminant transport models. Estuarine, Coastal and Shelf Science 39: 45-58

Turner A. 1996. Trace metal partitioning in estuaries: importance of salinity and particle concentration. Marine Chemistry, 54: 27-39.

Turner A., G.E. Millward \& S.M. Le Roux, 2004. Significance of oxides and particulate organic matter in controlling trace metal partitioning in a contaminated estuary. Marine Chemistry 88:179-192

Uncles R.J., 2003. From catchment to coastal zone: examples of the application of models to some long-term problems. The Science of Total Environment 314-316: 567-588

Westall J.C., 1987. Adsorption mechanisms in aquatic surface chemistry. In W. Stumm (ed.), Aquatic Surface Chemistry. Wiley-Interscience, New York. Pp 3-31

Westerlund SFG, Anderson LG, Hall PO, Iverfeldt A, Van der Loeff M, and Sundby B, 1986. Benthic fluxes of cadmium, copper nickel, zinc, and lead in the coastal environment. Geochim. Cosmochim. Acta. 50, p 1289-1296

Window HL, Smith RG, Maeda M, 1985. The gepchemistry of lead in rivers, estuaries and the continental shelf of the southeastern United States. Marine Chemistry 17, p 43-56

Wood T.M., A.M. Baptista, J.S. Kuwabara \& A.R. Flegal, 1995. Diagnostic modeling of trace metal partitioning on south San Francisco Bay. Limnology Oceanography 40: 345-358

Wu Y., Falconer R., Lin B., 2005. Modelling trace metal concentration distributions in estuarine waters. Estuarine, Coastal and Shelf Science 64, 699-709. 
Table 1. Particle geochemical characteristics and surface properties: mean values and relative standard deviation (RSD). Data from Dange (2002). These parameters are associated to equilibrium :

\begin{tabular}{|c|c|c|c|c|}
\hline & Mean & RSD (\%) & $n$ & n: number of measurements \\
\hline $\mathrm{SA} \mathrm{m}^{2} / \mathrm{g}$ & 6.0 & 32 & 21 & specific particle surface area \\
\hline CEC $\mathrm{mol} / \mathrm{g}$ of SM & $1.6910^{-4}$ & 30 & 24 & cation exchange capacity \\
\hline [-SOHtot] $\mathrm{mol} / \mathrm{m}^{2}$ & $2.9810^{-5}$ & 70 & 9 & total density of active surface sites \\
\hline Ka2 & $2.5710^{-5}$ & 13 & 10 & $\begin{array}{l}\text { Ka2: acidity intrinsic constants of } \\
\text { surface sites } \\
\text { [Seine estuary : single "average" type of } \\
\text { non-amphoteric surface site] }\end{array}$ \\
\hline $\log _{10} \mathrm{Km}$ & 0.48 & 52 & 7 & $\begin{array}{l}\text { Km: "global" intrinsic stability constant } \\
\text { of surface sites }\end{array}$ \\
\hline
\end{tabular}

Table 2 : Characteristics of "Marina" cruises

\begin{tabular}{|l|l|l|l|}
\hline Cruise & Date & Flow $\left(\mathrm{m}^{3} \mathrm{~s}^{-1}\right)$ & Zone covered \\
\hline Marina 3 & November 25-28, 1992 & 1000 & Rouen to Baie de Seine \\
\hline Marina 4 & September 9-19, 1994 & 300 & Tancarville to Baie de Seine \\
\hline Marina 5 & February 13-19, 1995 & 1400 & Tancarville to Baie de Seine \\
\hline Marina 6 & June 20-24, 1996 & 130 & Poses to Antifer (Baie de Seine) \\
\hline Marina 7 & 21 March - 1 April, 1997 & 400 & Vieux-Port to Baie de Seine \\
\hline Marina 8 & May 21-28, 1998 & 400 & Vieux-Port to Baie de Seine \\
\hline
\end{tabular}



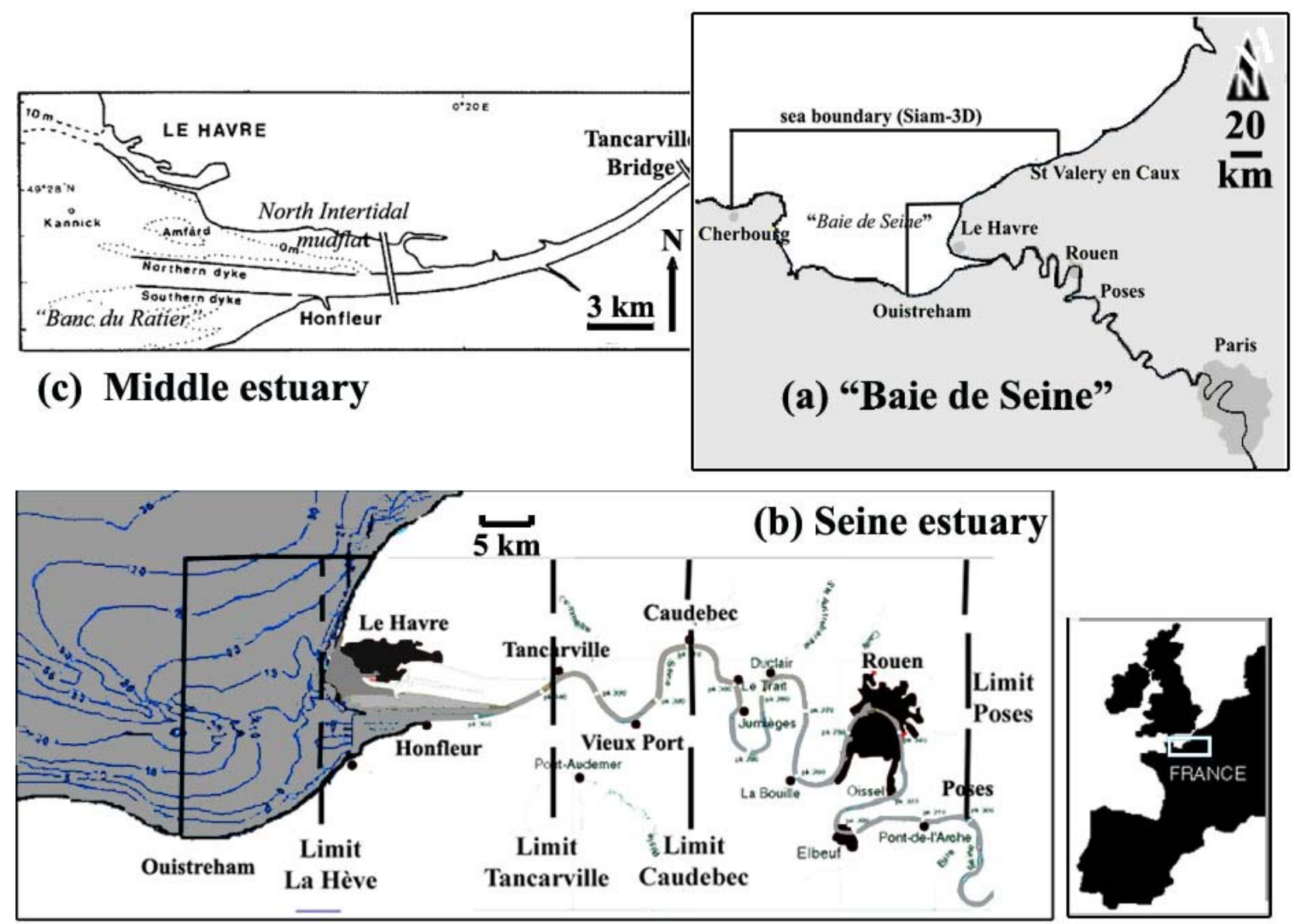

Figure 1: (a) Location of the Seine estuary and Baie de Seine (b) Position of transverse sections of computed fluxes (c) Detail of the Seine estuary mouth. 

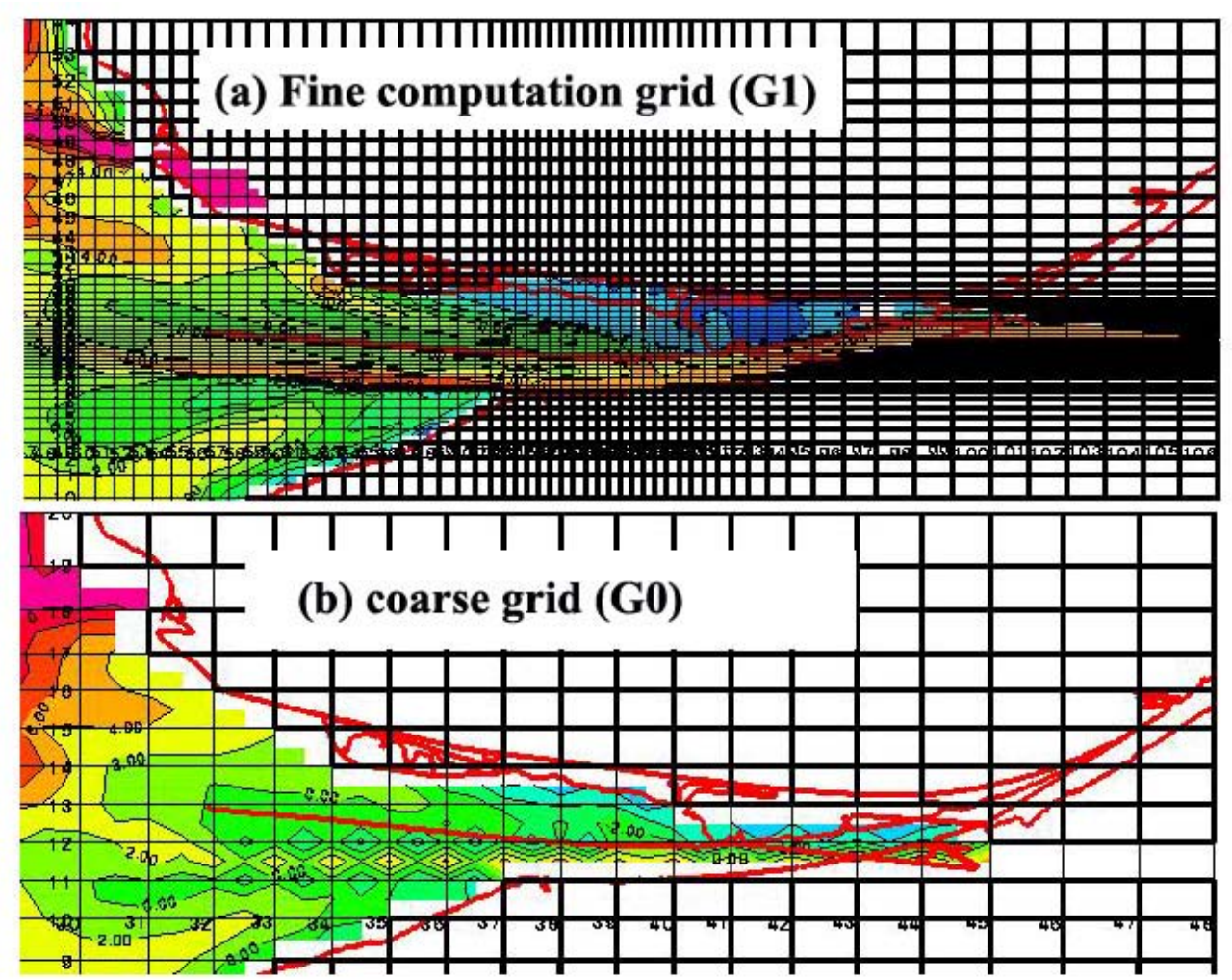

Figure 2: Details of the two computation grids in the middle estuary, between La Hève and Tancarville. (a) Fine grid G1- (c) Coarse grid G0

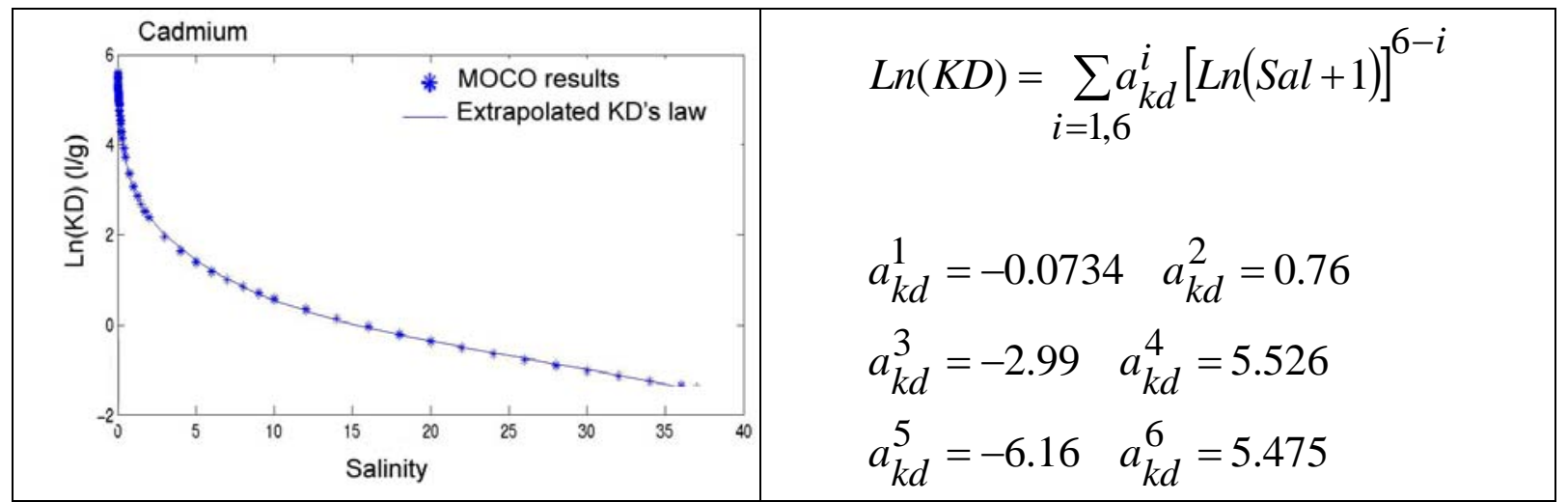

Figure 3: Cadmium partition coefficient computed by MOCO (dissolved vs. "exchangeable" sorbed partition).

Average parameters - Sulfate calculated according to salinity - no $\mathrm{pH}$ influence in the Seine 


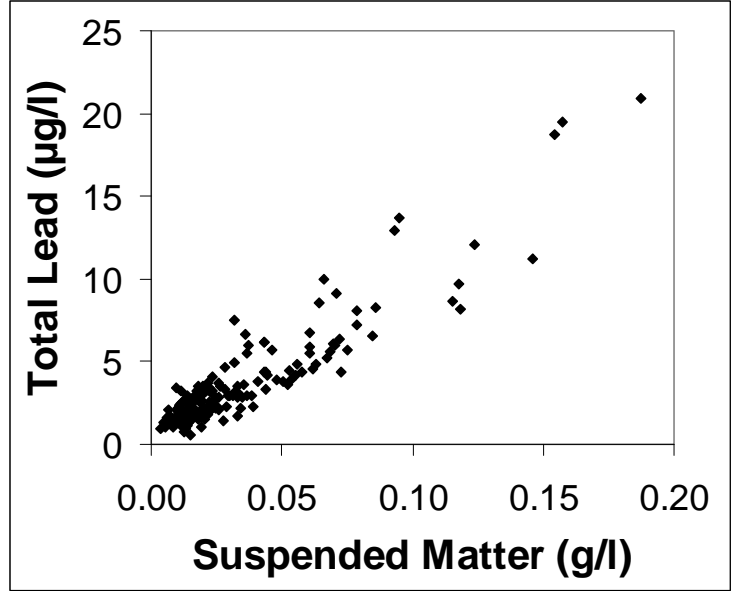

(a)

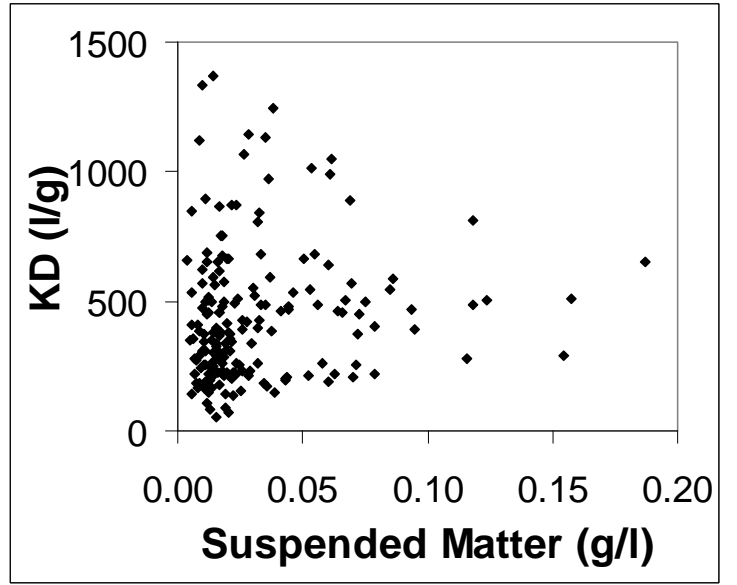

(b)

Figure 4 : Example of measurements of (a) total lead, and (b) partition coefficient in the upstream river (Poses) according to SM concentrations (Service de Navigation de la Seine, 1988 to 2001) 


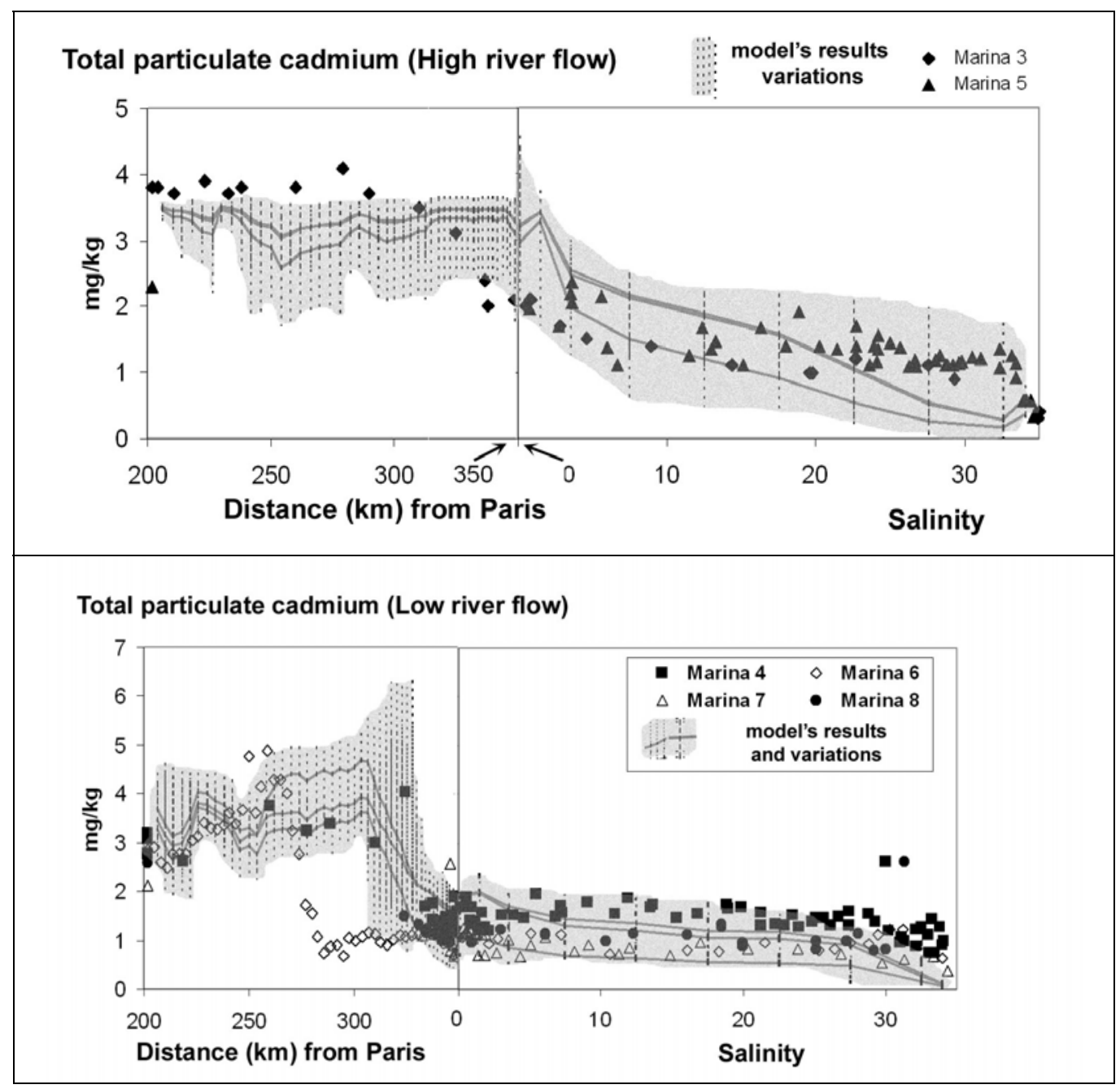

Figure5a: Comparison of total particulate cadmium measurements and model results in the Seine estuary during high river flow (top) and low river flow (bottom). Plot over distance in fresh waters and salinity in salt waters. 


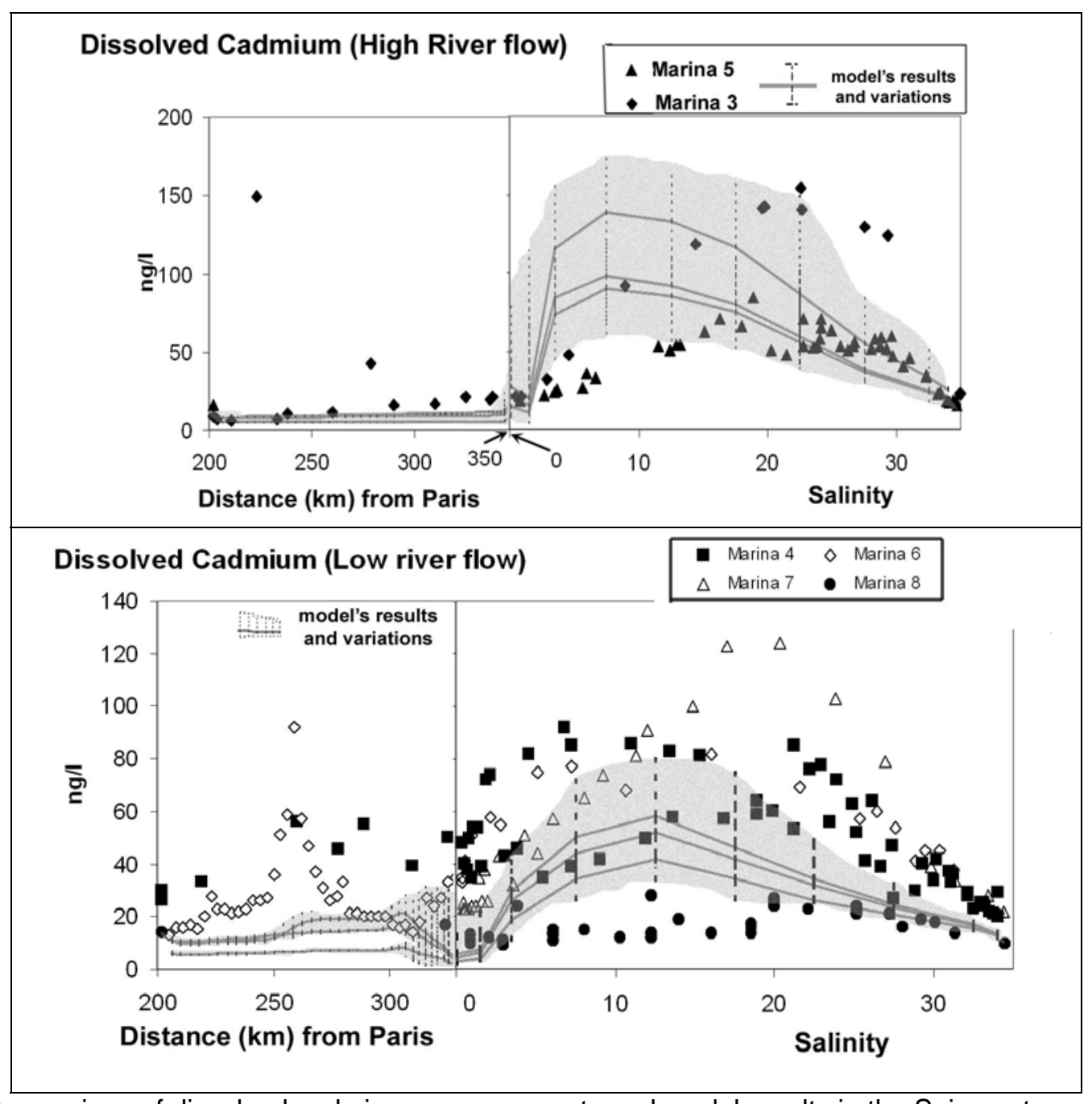

Figure 5b: Comparison of dissolved cadmium measurements and model results in the Seine estuary during high river flow (top) and low river flow (bottom). Plot over distance in fresh waters and salinity in salt waters. 


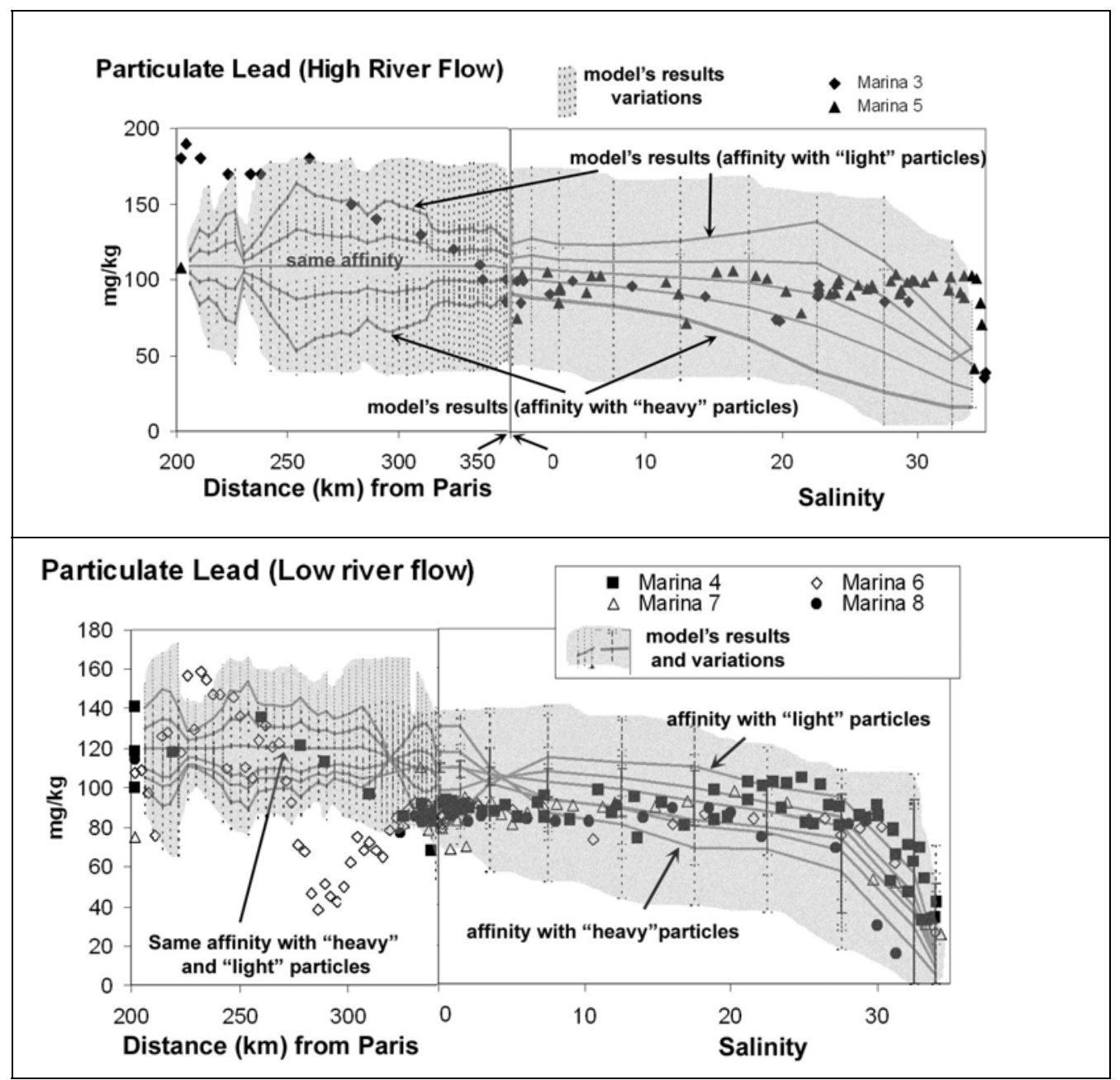

Figure6a: Comparison of total particulate lead measurements and model results in the Seine estuary during high river flow (top) and low river flow (bottom). Plot over distance in fresh waters and salinity in salt waters. 


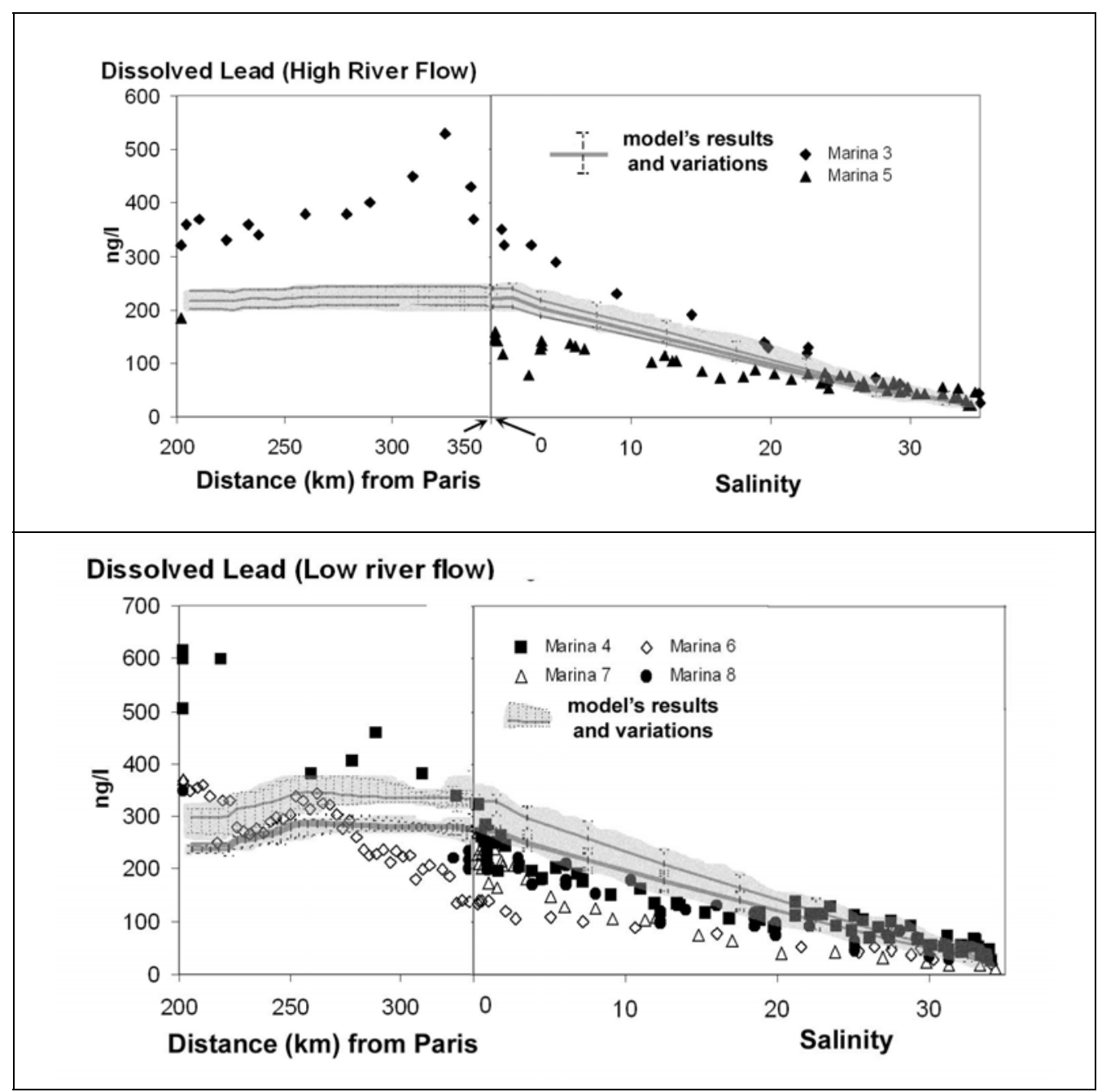

Figure 6b: Comparison of dissolved lead measurements and model results in the Seine estuary during high river flow (top) and low river flow (bottom). Plot over distance in fresh waters and salinity in salt waters. 


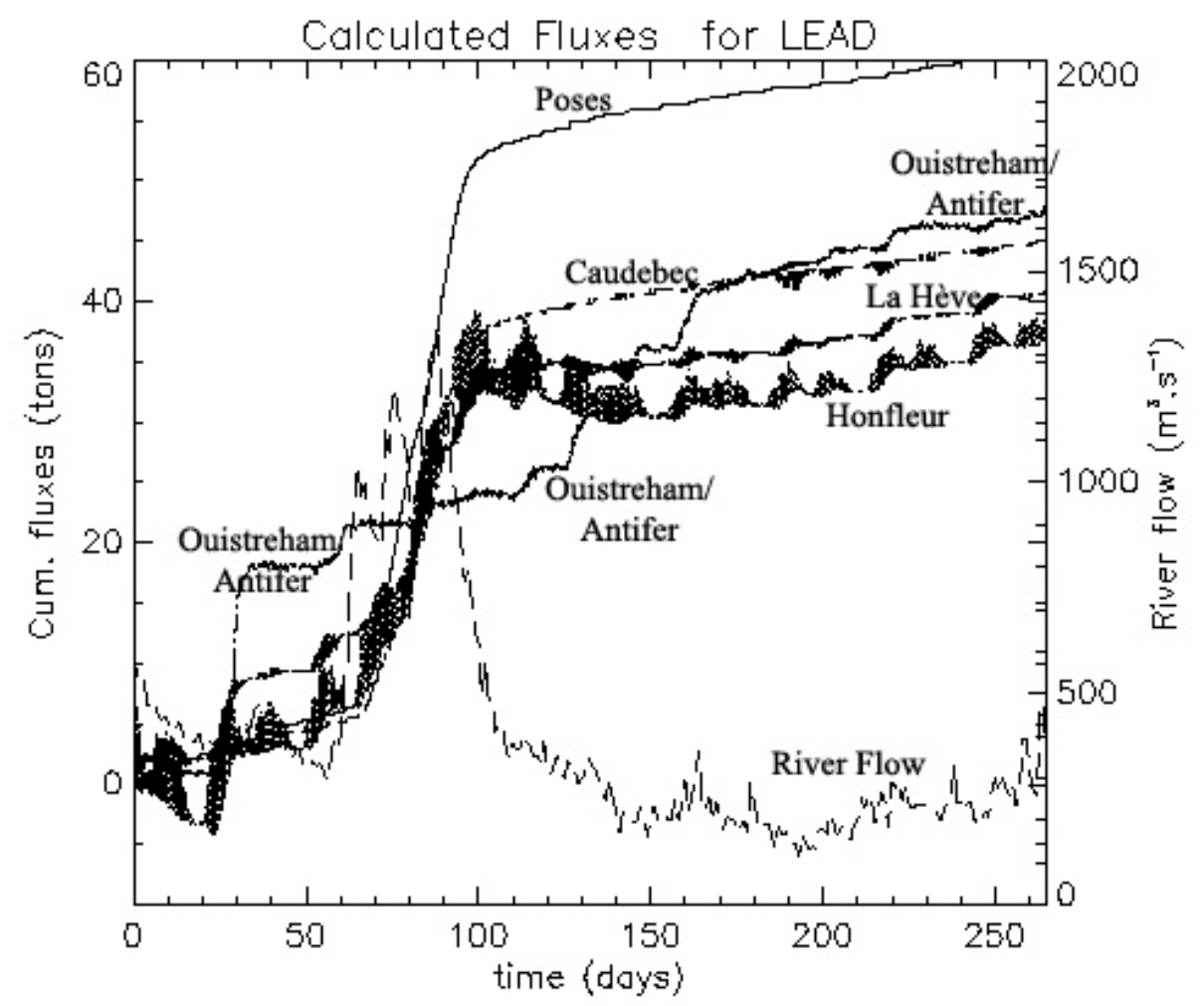

Figure 7: Computed cumulated fluxes of particulate lead in different sections of the Seine estuary through 9 months. Poses (dynamic tide limit), Caudebec (upstream estuary), Honfleur (salinity front), La Hève (open mouth), Ouistreham/Antifer (eastern bay) (see Figure 1b) 


\section{Cumulated fluxes of Suspended Matter}
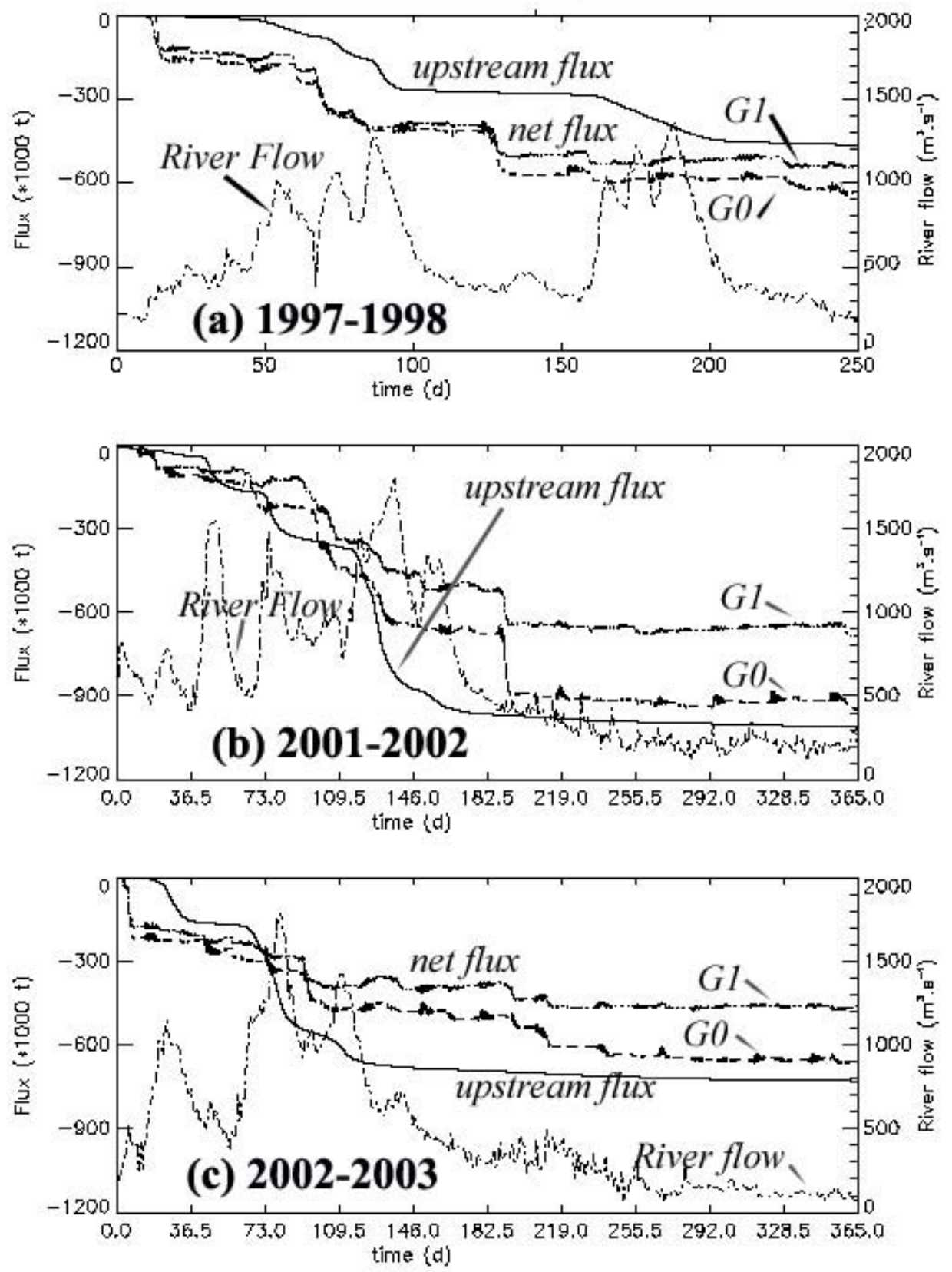

Figure 8: Comparison of cumulated particulate fluxes computed with fine and coarse grid at the upstream and sea boundaries during three time periods: (a) 1997-1998; (b) 2001-2002; (c) 2002-2003. 


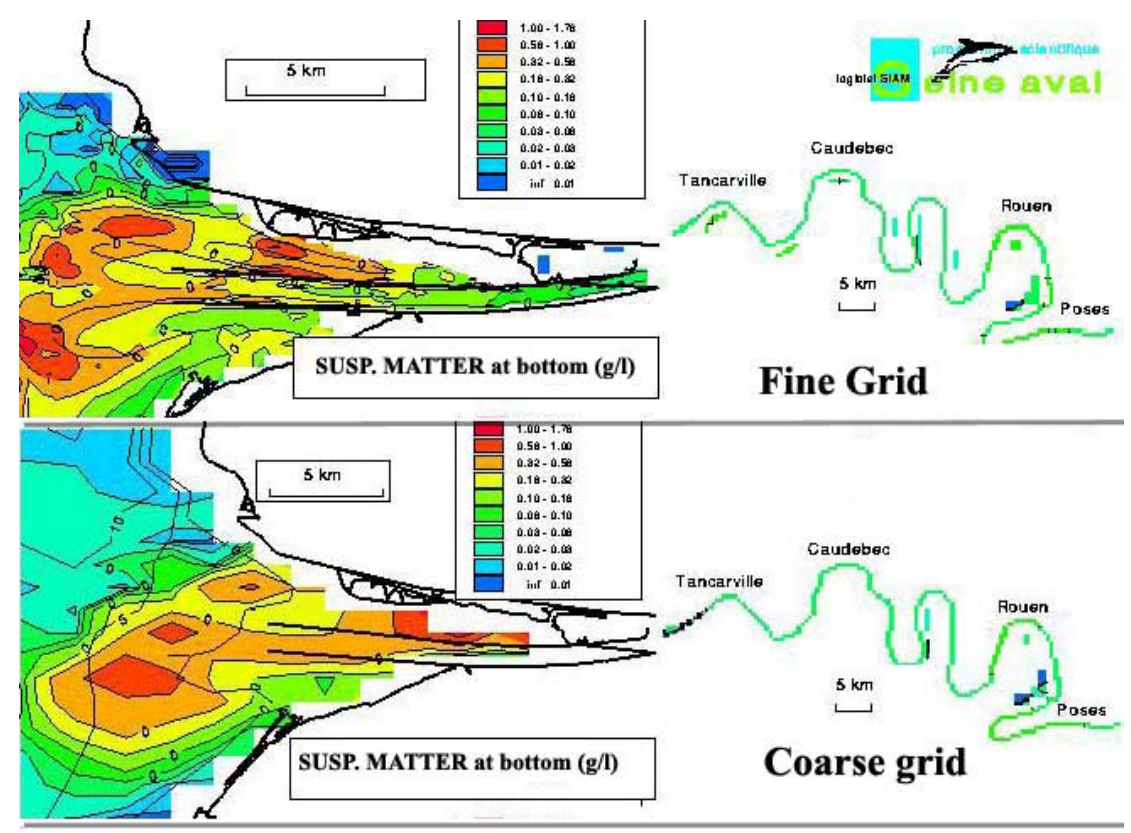

Figure 9: Fine sediment patterns calculated using two computation grids during low water spring tide

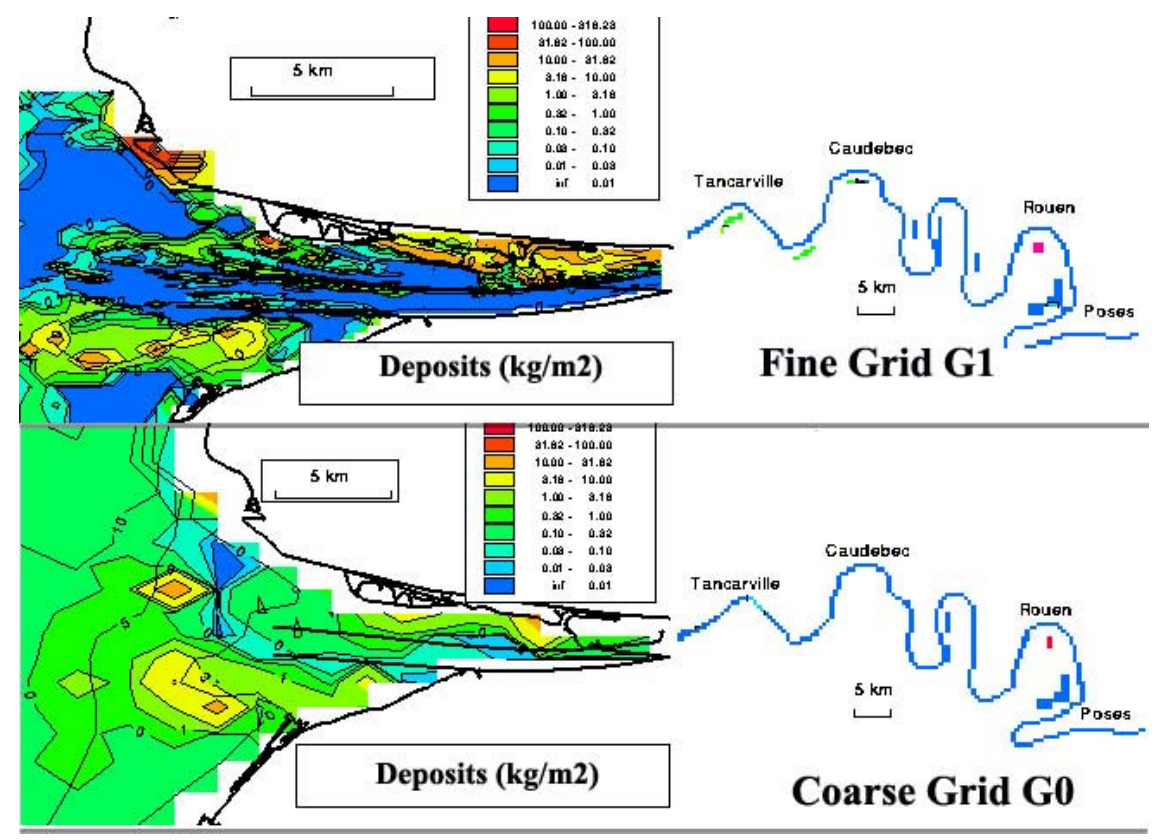

Figure 10: Minimum deposits calculated using two computation grids during neap tide 